\title{
Glaxo benches top manager
}

\section{London}

WHAT should a successful research organization do when one of its leading research managers decides he would like to return to the laboratory bench? For Glaxo, the answer is to spend $£ 16$ million to move the manager, complete with research team, to a laboratory in one of the country's best university pharmacology departments.

Not every company is able to make such a decision. But it is a bit easier when one is the world's second largest pharmaceutical company, and one's manager once discovered a drug that is on the brink of

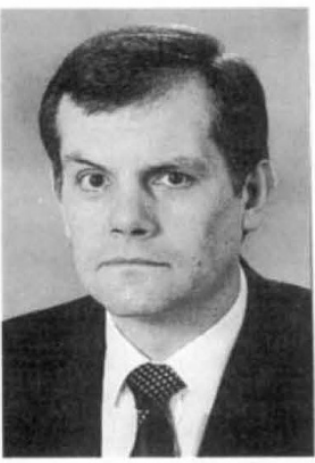

earning the com p a n y count les millions of pounds.

Under an agreement signed this week, Patrick Humphrey, director of pharmacology with the UK company Glaxo, will set up shop this spring in an

Glaxo's Pat Humphrey prepares for encore. right balance between promotion opportunities for managers and for researchers. "It's not a particular problem for us," says Keith Bradford, research and development personnel director with SmithKline Beecham. Norman Elmore, a research manager with ICI Pharmaceuticals, says that his company has comparable promotion ladders for scientists who choose to stay in research and those who move into management.

Maybe so. But as Humphrey points out, those companies have not had to contend with the rapid growth that Glaxo has experienced. "I think it's remarkable that Glaxo has managed to grow at the rate that it did without losing its way," he says.

Glaxo's growth has been formidable. In 1972, when Humphrey joined the company, Glaxo spent a mere $£ 7$ million on research and development; today, the figure is more than $£ 450$ million. On the strength of its research, Glaxo has been transformed from a nondescript food and drugs outfit into a company selling more than $\$ 6,000$ million worth of pharmaceutical products each year. That is a figure bettered only by its US rival, Merck and Co.

Almost 50 per cent of these sales come from a single product, the ulcer drug Zantac, or ranitidine. The drug that Glaxo hopes will continue this success Imigran, or sumatriptan - was based on Humphrey's research into the neurotransmitter serotonin. Imigran, which is used to treat migraines, has already been licensed in several European countries, and is expected shortly to win approval from the US Food and Drug Administration.

Humphrey's new institute in Cambridge is designed to provide future generations of big-earning drugs for Glaxo. Together with a small team of Glaxo researchers (several of them also research managers returning to the laboratory), Humphrey will move in April to Cambridge from Glaxo's research site at Ware, in Hertfordshire.

Pharmaceutical companies have set up research groups in British universities in the past - SmithKline Beecham, for example, has a 12-person unit in the University of Oxford's clinical pharmacology department. But Humphrey is adamant that the Glaxo/Cambridge arrangement (which will earn the university some $£ 5$ million over the next 10 years) will be much more focused on drug discovery than its predecessors. And he is confident that his years spent in research management will not be a serious disadvantage.

"I've done it once, and I can do it again. I've never been far from the centre of research," says Humphrey.

Peter Aldhous

\section{Patents, round two}

\section{Washington}

Following their controversial application last summer for patents on $\mathbf{3 4 7}$ partial human gene sequences, US government lawyers filed a patent last week for another 2,375 gene fragments.

The filing, which brings the government's total claim to about three per cent of the human genome, coincided with the publication in Nature of a paper by $\mathrm{J}$. Craig Venter, a National Institutes of Health (NIH) geneticist who identified the sequences. In explaining the reasons for the second filing despite widespread criticism of its predecessor, NIH director Bernadine Healy said that her agency was taking the only prudent course, given the present uncertainties in patent law. She described it as an "interim policy" that would ensure that NIH do not lose any possible property rights should the sequences turn out to be patentable, while allowing researchers and the biotechnology industry to continue their debate.

Although the idea of patenting gene sequence in which the functions of the genes is unknown is still anathema to many researchers, the consensus has shifted towards the NIH since last year's protests (see Nature 353, 485; 1991). Given the possibility that the sequences could be found patentable even without known function, biotechnology industry associations and many patent experts now say that NIH had little choice but to file an application, lest a private company of foreign company do it first. Biotechnology companies would be more supportive, however, if they knew just how NIH would license the sequences if the patent is granted.

Reid Adler, director of the NIH's technology transfer office, says that the agency intends to consult with industry to develop such a policy. "We want to be very fair and very open about this," he says. He will be meeting with the Industrial Biotechnology Association this week.

Christopher Anderson SPACE RESEARCH

\section{NASA chief sacked}

Washington

ADMIRAL Richard Truly, who as head of the National Aeronautics and Space Administration (NASA) helped the agency recover from the 1986 explosion of the space shuttle Challenger, was fired last week in a policy battle over the future direction of the agency. Although Truly's departure after nearly three years at the helm will go down in the books as a resignation, the former astronaut made no secret of the fact that he had been told to leave by President George Bush.

Truly will depart 1 April. No replacement has been named.

Christopher Anderson 